\title{
Why Is Family-Oriented Organ Transplantation Policy and Practice Necessary for Bangladesh?
}

\author{
Md. Sanwar SIRAJ, Ph.D.
}

Assistant Professor, Department of Government and Politics, Jahangirnagar University, Savar, Dhaka-1342, Bangladesh, Email: siraj_sanwar@juniv.edu

DOI: https://doi.org/10.3329/bioethics.v11i1.49191

\begin{abstract}
In the West, in countries such as the US and UK, people are equally encouraged to donate organs both to their relatives and nonrelatives. In practice, although family is the priority in the US and UK, anybody can donate organs to anyone else lawfully. Contrastingly, in Bangladesh, people are only legally allowed to donate organs for transplantation to close relatives. Bangladesh's living organ transplantation policy and practice is in stark contrast with the Western secular biomedical perspective. In this artcile, I address that the notion of individual freedom and liberty in regard to the donation of organs for transplantation in the West is consistent with secular culture and biomedical perspectives, but such biomedical policy and practice is at odds with the Bangladeshi Muslim culture, socio-economic reality and biomedical perspective. As Bangladesh is a family-oriented collective society, the kinship relation and strong familial bonds may encourage relatives into donating organs to a patient. More than $20 \%$ of people still live below the poverty line, and the COVID-19 pandemic has pushed poor people into extreme poverty. The practice of allowing unrelated altruistic donors as is done in the West and Iran, or even in the special circumstance in Paksitan, the act of donating organs will comprehensievly increase organ trade in Bangladesh, which in turn will cause more harms than benefits. This study conludes that the government should uphold family-oriented biomedical policy and practice in Bangladesh until poverty is eliminated. It implies that patients who do not have close relatives, or whose poetntial relative donors are medically unsuitable for transplantations should wait for deceased organs for transplantation.
\end{abstract}

Key words: Family, Organ Transplantation, Policy, Bangladesh

Introduction: The first sucecssul organ transplantation between close relatives was performed in Bangladesh in 1982, and the practice became more regular from $1988^{1}$. Untill the legislation of 1999, there was no legal provision in relation to organ donation for transplantation in Bangladesh. The Human Organ Transplantation Act (HOTA) was first approved in 1999. The act allowed organ donations from both living donors and brain dead donors for transplantation. For living donations, a number of close family relatives were lawfully allowed to donate organs for transplantation. The act was then revised in 2018 that added a number of extended family relatives as potential donors to the existing donor list. The revised act upholds the family-oriented nature of biomedical policy. Despite the transplantation of corneas from brain dead donors having commenced in Bangladesh, the transplantation of vital organs (e.g., kidney, liver, heart and pancreas etc.) has not yet been introduced ${ }^{2}$. The government of Bangladesh recently attempted to initiate a program of transplantation of vital organs from brain dead donors.

Conversely, in the West, in countries such as the US and UK, people are equally encouraged to donate organs both to their 
relatives and non-relatives ${ }^{2,4}$. In practice, although family is the priority in the US and UK anyone can lawfully donate organs to anyone else. Unrelated altruistic donors are legally allowed to donate organs in the Islamic Republic of Iran if a patient is unable to find a potential donor from inside their own family, and also donation from the deceased is permitted ${ }^{5-}$ ${ }^{8}$. In the Islamic Republic of Pakistan, if a related donor is not avilable, or if such potential donors are incompatible with the patient, an unrelated donor can donate organs on the condition that the Evaluation Committee (EC) is satisfied that such a doantion is "coercion-free" and "voluntary".

A small group of libertarian Bangldaeshis recently put pressure on the governement of Bangladesh so as to extend the biomedical policy and practice beyond just relatives as is done in the West, arguing on the grounds of individual liberty and freedom that public policy does not prohibit someone from donating organs. Some even urge to the government to extend biomedical policy and practice, likley as using the model of Iranian practice. Some threfore urge the governement to allow unrelated altruistric donations conditionally in special circumstances as in Pakistan. They view that extending bioemdical policy and practice to beyond relatives in Bangladesh will save the lives of many patients, and will cause greater benefits than harms. I contend that the government should uphold the family-oriented character of bioemdical policy and practice of living organ donation for transplantation in Bangladesh until poverty is eliminated. The practice of allowing unrelated altruistic donors to donate organs lawfully will force poor people into selling their organs to alleviate poverty.

Stipulations of the Policy and Practice of Living Organ Donation for Transplantation in Bangladesh: The Human Organ Transplantation Act (HOTA) was first passed by the Bangladesh Parliament in 1999, allowing both brain dead donors, and living related donor transplantations. According to the 1999 act, the first degree blood relatives such as the father and mother, adult sons and daughers, adult sisters and brothers, and second-degree relatives by blood are the uncles and aunts both from paternal and maternal sides, and emotional relatives such as husbands and wives are the only people who can legally donate organs for transplantation (Section 1: 4). The existing act that was revised in January 8, 2018 and came into force officially on January 28, adds a number of extended family relatives to the existing donor list. The act redefines the term 'close relatives' and adds a number of third-degree blood relatives, namely grandparents, grandchildren and first cousins (Section 1: 4). Apart from these family relatives, unrelated donors are not legally allowed to donate organs for transplantation in Bangladesh. The stipulation of the new act also adds that anybody can donate skin, tissues, bone marrow and corneas to anyone else (Section 3:1), but that vital organs (e.g., kdiney, liver, and pancreas etc.) are to be donated only among these relatives listed in the act. The act does not allow the selling of organs or receiving of financial benefits for donating organs. It also completely prohibits advertisements for the purpose of selling organs (Section 9). Thus the policy and practice of living organ transplantation in Bangladesh has 
remained family-oriented because unrelated altruistic donors are not lawfully allowed to donate organs for transplantation.

\section{Stipulations of the Policy and Practice} of Living Organ Donation for Transplantation in the West: In the US and UK, people are equally encouraged to donate organs both to their relatives and non-relatives ${ }^{3,4}$. In practice, depite family members being the priority in the US and UK, anyone can lawfully donate organs to anyone else. In the UK, for example, a living donations can be classified consequently as a directed altruistic donation, non-directed altruistic donation, paired/pooled donation or non-directed altruistic donor chain donations. The first category of donation, directed altruistic donation, is where an individual can donate an organ to a family member, partner or good friend. Donating organs to someone with whom donors have no genetic or pre-existing emotional relationship with is called a non-directed altruistic donation. If a donor is not medically suitable for someone whom they wish to donate to, they may join a joint scheme and be matched with another donor recipient pair in the same situation, so that more than two people in need of a transplant are able to exchange compatible organs. In the final category, the nondirected altruistic donor can donate their organ into a paired/pooled scheme. By matching two or more potential donors and recipients, a chain of operations can be carried out. At the end of the chain, the remaining organ is then donated to the best-matched patient on the basis of a national waiting list $^{3}$. I contend that as Bangladesh is a family-oriented collective society ${ }^{1}$, introducing the UK biomedical policy and practice of living organ transplantation into a non-Western country is culturally and socio-economically at odds, and such policy and practice would encourage poor Bangladeshis to sell their organs to to non-blood relatives to alleviate poverty.

Why is Western living organ
transplantation policy and practice
inappropriate with $\begin{gathered}\text { Bangladeshi } \\ \text { indigenous culture, socio-economic }\end{gathered}$
situation and biomedical perspectives?
As mentioned earlier, people in the West such as the US or UK are equally encouraged to donate organs both to their relatives and nonrelatives. In practice, although family is the priority in the US or UK anyone can lawfully donate organs to anyone else. This article argues that Westerners are free, autonomous, independent and rational individuals and this gives individuals the right to make their own decisions regarding organ donation for transplantation. Western secular values stipulate that humans should be treated equally, that individual autonomy should be the basis of all national activities, and that biomedical laws and practices should be guided by the Western emphasis on individual autonomy, equality and freedom of choices ${ }^{10}$. Westerners hold the view that as long as people abstain from doing harm, they should be permitted to donate to anyone they choose. As Westerners also believe that organ donation is an altruistic activity as a gift of life, so, these charitable and altruistic activities should not be limited to relatives only. Conversely, I contend that traditional family bonds and relations in the West are not strong enough, but have become broken and strained ${ }^{11}$, secularminded, freely-motivated Western people 
are not obliged to only donate to family members. Thus, modern secular biomedical policies and practices allow anybody in the West to donate freely to anyone they wish.

I argue that the Bangladesh governemnt ought not to establish the Western approach of individual freedom, equality and free choice in biomedical policy that legalises donations to both family members and unrelated patients. Despite the difference of the survival rate between unrelated and related donor-recipient pairs not being statistically significant, I contend that Western individual free choice is inappropriate for a non-Western country whose cultural ties are strongly connected with the community such as the family. The application of such secular Western values to biomedical decisions are contrary to the Islamic emphasis on religious dignity and the Muslim tradition of collective decision-making ${ }^{12}$, which prioritizes non-individualist values. Establishment of the Western biomedical approach in the Muslim society of Bangladesh would thereby cause enormous societal, economic and familial problems.

If the government established Western secular biomedical policy in Bangladesh, it may encourage donors to donate both to families and unrelated patients, and as such will increase the organ trade in Bangladesh. In the name of altruistic motivation, poor Bangladeshis may easily sell their organs to alleviate their poverty. I argue that if Bangladesh's governemnt endorses Western biomedical policy, such as that of the UK, it will cause more organ business in Bangladesh. I argue that extending biomedical policy beyond family relatives would make Bangladeshi families more vulnerable and perilous. In the name of respecting individual freedoms, as in Western cultures, or saving the lives of vulnerable patients, the extension of biomedical policy to unrelated donors would place poor Bangladeshis into markets as daily commodities. Organ selling is an immoral practice ${ }^{13-22}$, because potential donors and recipients involve bargaining position for organs what sellers and buyers do in markets for a commodity exchange ${ }^{1}$. These immoral practices should not be allowed in Bangladesh.

Despite individuals being seen as possessing the human right to donate organs to anyone else altruistically, I argue that allowing unrelated altruistic donors to donate organs legally on the grounds of individual rights, social justice or equity would be unrealistic and unjustified for Bangladeshis. As Bangladesh is a familyoriented collective society and almost all Bangladeshis are born, raised and live in the familial structure, the kinship relation and familial bond may encourage Bangladeshis to donate organs to their ill patients ${ }^{1}$. As the government has already extended the donor list to include thirddegree blood relatives, Bangladeshi patients may find potential donors from inside their own families. Allowing a Western-style free donation system may create social burdens for Bangladeshis. Allowing unrelated donors to donate organs legally will compromise the strengh and integrity of the family. If unrelated patients are lawfully allowed to receive organs, rich patients will easily buy organs from the poor, and Bangladeshi families may no longer be able to find donors inside their own familiess in their time of 
need ${ }^{1}$. Almighty surely has defined limits for the use of the body. Scholars permit Muslims to donate organs to their relatives even though it may risk one's life to save another, this belief prohibits Muslims from donating organs to unrelated patients 13,14 Also, saving the life of a relative by donating organs is more valued in Islam as the Qur'an states “And give to the near of kin his due and [to] the needy and the wayfarer, and do not squander wastefully" (Qur'an, 17:26).

Some argue that how could Bangladeshi practice save the life of an orphan who does not have any relatives? The view that as organ donation for transplantation is a charitable and humanitarian activity, the public policy does not and can not prohibit individuals from donating their organs to anyone else, because the aim of public policy is to ensure benefits rather than harms for all members in the society. I contend that as these cases are very few, allowing unrelated altruistic donors to donate organs legally in order to save the lives of a few orphans may create many social problems in Bangladesh that would outweigh the total benefits. Allowing unrelated donors to donate organs to save the lives of orphans may encourage poor people to sell organs. If orphans do not have relatives, they should wait for deceased donation for transplantation. As the government is recently trying to establish transplantation of vital organs (e.g., kidney, liver, heart, and pancreas etc.) from brain dead donors, the successful immediately introduction of a program allowing deceased organ donation for transplantation would be a good solution for saving the lives of orphans and other patients. Otherwise, permitting unrelated donors to save the lives of few orphans may severely increase organ trade in Bangladesh, causing more harm than good.

Stipulations of the Policy and Practice of Living Organ Donation for Transplantation in Iran and Paksitan: Some refer to the policy and practice of living organ transplantation in the perspective of Iran where unrelated donors can donate organs for transplantation. Let me berifly discuss the policy of living organ transplantation in Iran. Once a patient is identified, medical professsionals search for a medically-suitable living related donor for transplantation. In doing so, physicians advise the patient to find a potential donor within their family ${ }^{23}$. If a patient does not have any related potential donors, or a potential relative donor is not willing to donate, then the recipient is referred to the Dialysis and Transplant Patients Association (DATPA) to find an organ from a deceased donor (DD), waiting in the queue for a maximum of six months ${ }^{8}$. If the patient does not find an organ from a DDs the DATPA searches for suitable organs from living unrelated donors $(\mathrm{LUD})^{8}$. LUDs receive a fixed amount of compensation (10 million Iranian rials), one year post-operative medical insurance, medicines at subsidized costs, and waived hospital fees from the government or charities after transplantation ${ }^{7}$. LUDs also receive extra financial compensation from recipients for their donation ${ }^{7}$. If such unrelated donation is adopted in Bangladesh, the poor will easily sell their organs to rich patients to get out poverty, in line with what happens in Iran ${ }^{24,25}$. This biomedical policy and practice should not be introduced in Bangladesh, as the harm it causes will outweigh benefits. 
Some even refer to the biomedical perspective of Paksitan where unrelated altruistic donors are conditionally allowed to donate organs for transplantation in special circumstances. Let me briefly discuss the stipulations of the policy and practice of living organ donation for transplantation in Pakistan. An unrelated altruistic donor is allowed to donate organs only in the situation when close relative donors such as parents, adult progeny, adult siblings, and spouses are not available and/or such potential relative donors are medically unsuitable for transplantation. In the case of unavailability of such close relatives, the law prescribes that the EC may permit donation by unrelated donors only after satisfying the EC that such a donation is fully "voluntary" and "coercion-free" 9 . Some Bangladeshis argue that if Pakistan, being a South Asian Muslim society, can allow unrelated altruistic donors to donate organs for transplantation in special conditional circumstances, the Bangladesh governemnt should also allow the same practice. I contend that Bangladesh's biomedical policy already allows a wider number of relatives (e.g., parents, adults progeny, adult siblings, spouses, paternal and maternal uncles and aunts, grandparents and grandchildren, and first cousins) to donate organs for transplantation, while in Pakistan the number of potential donors is fewer (i.e., parents, adult sons and daughters, sisters and brothers, and spouses). Bangladeshi patients are thus more likely to find a potential donor from inside their family. To cite the view of Moniruzzaman (2010); extending biomedical policy to beyond relatives is a concession of a few rich patients who might want to avoid harming the body of their own relatives, and instead try to obtain an organ donation from a poor person ${ }^{2}$. Despite the Bangladesh governemnt having extended its biomedical policy to third-degree blood relatives, I agree with the view of Moniruzzaman (2010) that it is the corrupt intention of a few rich patients to buy an organ from a poor person instead of obtaining it from their relative ${ }^{2}$. As more than $20 \%$ of people still live below the poverty line ${ }^{26}$, and the COVID-19 pandemic pushes poor people into extreme poverty and makes others economically vulnerable (27), allowing unrelated donors to donate organs even in special cases will severely increase the organ selling problem in the country. In the name of altruistic donations, poor people will easily sell their organs to rich patients to get away from poverty, thereby outweighing possible benefits.

In addition to the poor socio-economic conditions of people in Bangladesh, I also argue that allowing unrelated donors to donate organs lawfully will severely increase organ trading in Bangladesh, where there is no effective accountability mechanism, and corruption has been a burden for many years ${ }^{28}$. For instance, in 2012, TI ranked Bangladesh as the thirteenth most-corrupted country in the world $^{29}$. In 2015, the National Household Survey on Corruption in the Service Sectors of Bangladesh estimates the cost of bribery in regard to unauthorised and informal payments annually to be 8,822 crore BDT, which equals $0.6 \%$ of the Gross Domestic Product (GDP) ${ }^{30}$. In this reality, allowing unrelated donors to donate organs lawfully will comprehenssively increase the organ trade in Bangladesh, which may negatively 
affect the health of larger sections of the population. The vested interest groups such as rich patients and brokers will be the only beneficiaries of such an extension to bioemdical policy and parctice.

Concluding Remark: The policy and parctice of living organ donation for transplantation in Bangladesh should be family-oriented until poverty is eliminated. Otherwise, allowing unrelated donors to donate organs to anyone else or in special circumstances will encourage poor Bangladeshis to sell their organs to get away from poverty. The successful implementation of a program for deceased organ donation for trasnplantation may save the lives of many patients, especially those whose who do not have potential relative donors avilable, or if they do, are medically incompatible with their relatives. Bangladeshi policy makers, health professionals, legal experts, transplant communities and bioethicists should consider this with the utmost attention.

Acknowledgments and Funding Information:I deeply acknowledge the suggestions that I received from my Ph.D. supervisor, Professor Ruiping Fan. I am also thankful to Dr. Rebecca Dewey, University of Nottingham for providing me with meticulous editing work on the manuscript. A part of this study was supported by the Research Activities Fund (Grant Number: 000669), University Grants Committee (UGC) of Hong Kong.

\section{References:}

1. Siraj MS. Organ Donation for Transplantation in Bangladesh: Policy, Practice and Ethics. PhD thesis: City University of Hong Kong, HKSAR; 2016.

2. Moniruzzaman Md. "Living Cadavers" in Bangladesh: Ethics of Human Organ Bazar. PhD thesis, University of Toronto, Canada; 2010.
3. Human Tissue Authority. Types of living organ donation [Internet]. Human Tissue Authority. $2018 \quad$ [cited 2020 Aug 27]. Available from: https://www.hta.gov.uk/guidan ce-public/living-organ-donation/types-living-organdonation.Accessed on 1 April 2019

4. Nathan HM, Conrad SL, Held PJ, McCullough KP, Pietroski RE, Siminoff LA, et al. Organ donation in the United States. Am J Transplant. 2003 Apr;3(s4):29-40.

5. Ghods AJ. The history of organ donation and transplantation in Iran. Exp Clin Transplant. 2014;12(SUPPL. 1):38-41.

6. Ghotbi N. The ethics of organ transplantation in the Islamic Republic of Iran. Eubios $J$ Asian Int Bioeth. 2013;23(November):190-3.

7. Mahdavi-Mazdeh M. The Iranian model of living renal transplantation. Kidney Int. 2012;82(6):625-6.

8. Hammond S. How Iran Solved Its Kidney Shortage, And We Can Too. Washington, D.C.; 2018. [cited $2020 \quad$ Aug 26]. Available from https://www.niskanencenter.org /how-iran-solved-its-kidney-shortage-and-we-cantoo/ Accessed on 1 February 2019

9. The Transplantation of Human Organs and Tissues Act of Pakistan. Pakistan; 2010. [cited $2020 \quad$ Aug 26]. Available from http://punjablaws.gov.pk/laws/2428 a.html.

10. Childress JF, Beauchamp TL. Principles of Biomedical Ethics. 7th ed. New York: Oxford University Press; 2009. 1-455 p.

11. Cherry MJ. Individually Directed Informed Consent and the Decline of the Family in the West. In: Fan R, editor. Family-Oriented Infromed Consent: East Asian and American Perspectives. Springer, Dordrecht; 2015. p. 43-62.

12. Siraj MS. Beyond Western Conservatives and Progressive Liberals: A Moderate Islamic View. Int J Chin Comp Philos Med. 2014;12(2):16, 135-9.

13. Moazam F. Bioethics \& Organ Transplantation In A Muslim Society: A Study in Culture, Ethnography and Religion. USA: Indiana University Press; 2006. 1-264 p.

14. Moazam F. Sharia Law and Organ Transplantation: Through the Lens of Muslim Jurists. Asian Bioeth Rev. 2011;3:316-32. 
15. Ismail SY, Massey EK, Luchtenburg AE, Claassens L, Zuidema WC, Busschbach JJ V, et al. Religious attitudes towards living kidney donation among Dutch renal patients. Med Health Care Philos. 2012;15(2):221-7.

16. Rizvi AHS, Naqvi ASA, Zafar NM, Ahmed E. Regulated compensated donation in Pakistan and Iran. Curr Opin Organ Transplant. 2009;14(2):124-8.

17. Naqvi SAA, Ali B, Mazhar F, Zafar MN, Rizvi SAH. A socioeconomic survey of kidney vendors in Pakistan. Transpl Int. 2007;20(11):9349 .

18. Alkhawari FS, Stimson G V., Warrens AN. Attitudes toward transplantation in U.K. Muslim Indo-Asians in West London. Am J Transplant. 2005;5(6):1326-31.

19. Efrat A. The Politics of Combating the Organ Trade: Lessons From the Israeli and Pakistani Experience. Am J Transplant. 2013;13(7):1650-4.

20. El-Shahat YIM. Islamic Viewpoint of Organ Transplantation. Transplant Proc. 1999;31(8):3271-4.

21. Phadke KD, Anandh U. Ethics of paid organ donation. Pediatr Nephrol Berl Ger. 2002;17(5):309-11.

22. Natour A, Fishman S. Islamic Sunni Mainstream opinions on Compensation to Unrelated Live Organ Donors. Rambam Maimonides Med J. 2011;2(2):1-7.

23. Ghods AJ. Dialysis and Transplantation News Renal transplantation in Iran. Nephrol Dial Transpl. 2002;17:222-8.

24. Zargooshi J. Iranian kidney donors: Motivations and Relations with recipients. J Urol. 2001;165(2):386-92.
25. Koplin J. Assessing the likely harms to kidney vendors in regulated organ markets. Am J Bioethicsournal Bioeth. 2014;14(10):7-18.

26. Asian Development Bank. Poverty Data: Bangladesh [Internet]. Bangladesh and ADB. 2020 [cited 2020 May 13]. Available from: https:/www.adb.org/countries/bangladesh/poverty.

27. Ovi IH. Covid-19 fallout: Income drops to create $16.4 \mathrm{~m}$ new poor this year. Dhaka Tribune. 2020 Jun 24. [cited 2020 Aug 25]. Available from https://www.dhakatribune. com/business/economy/2020/06/24/bangladesh-tohave-16-4m-new-poor-in-2020.

28. Naher N, Hoque R, Hassan MS, Balabanova D, Adams AM, Ahmed SM. The influence of corruption and governance in the delivery of frontline health care services in the public sector: a scoping review of current and future prospects in low and middle-income countries of south and south-east Asia. BMC Public Health. 2020;20(1):1082.

29. TI. TI Corruption Perceptions Index. Berlin: Transparency International [Internet]. TI. 2012 [cited 2020 Aug 26]. Available from: https://www.transparency.org/en/cp i/2012\# Accessed on 1 April 2019

30. TIB. Corruption in service sectors: national household survey 2015 [Internet]. TIB. 2016 [cited 2020 Aug 26]. Available from: https://www.tibangladesh.org/beta3 /images/2016/es nhhs 16 en.pdf Accessed on 10 March2019

Author contribution: Author conceived the idea, did the literature review, wrote the manuscript and checked the manuscript meticulously.

Conflict of interest: The author declares that there is no conflict of interest in this study. 